\title{
Socio-economic empowerment of thick-tailed-sheep livestock 'through feed variation technology (feed fermentation)
}

\author{
Hairani Siregar, Etti Sartina Siregar \\ University of Sumatera Utara \\ Email: hairanisiregar71@gmail.com
}

\begin{abstract}
Community service is one of the obligations that should be carried out by each lecturer at the College as one aspect of Tri Darma College. This activity by Service Team is entitled: SOCIO-ECONOMIC EMPOWERMENT OF THICK-TAILED-SHEEP LIVESTOCK THROUGH FEED VARIATION TECHNOLOGY (FEED FERMENTATION) in SeiMencirim, DeliSerdang. For the people in Sei Mencirim, District of Sunggal, the main obstacle found in society is ignorance of the community to build the strength of the group into a powerful social energy in solving social problems in the community. Besides, it is also ignorance of the public to use agricultural waste which is commonly found in SeiMencirim in order to solve the economic problem in the community.By utilizing social resources and the natural resources that exist will result in a socially and economically strong community. Thus, the social and economy problems will be easily solved, which is based on the implementation of the people economy through socioeconomic empowerment to thick-tailed-sheep livestock through feed variation technology (feed fermentation).Improving the reproduction ability of thick-tailed sheep owing to fermentation feeding will eventually be able to increase the sheep population more quickly because the sheep will efficiently do their reproductive activity. The efficiency rise of reproduction is clearly going to increase livestock numbers quickly and more efficiently, as well as an increase in their income.
\end{abstract}

Keywords : Management, Livestock, Agricultural Waste, Feed Variation

\section{PRELIMINARY}

Diverse necessities of life continue to increase causing the public must always be creative in finding alternative productive activities. The main obstacle that is often found is the inability of villagers to indentified a potential source of social and natural resources owned. It takes the intervention of outsiders to encourage people to identify potential sources of social and natural resources available so that communities can make a map of a potential source of social and natural resources potential. One way to explore the available resources is by diversifying occupational sector to another. According Mubyarto (2002) one of the occupational diversification adaptation strategies that can be done by people less able to cope with the lack empowered.

The powerlessness of the conditions experienced by the people in the village of Sei Mencirim Sunggal District of Deli Serdang. For the people in the District Sei Mencirim proposer Sunggal main obstacles found in society is ignorance of the community to build the strength of the group into a powerful social energy in solving social problems in the community. Besides it is also ignorance of the public using agricultural waste which is commonly found in SeiMencirim in order to solve the economic trouble in the community.

Agricultural land is very spacious with various plant varieties can be found in the village of Sei Mencirim. In general, in the village of Sei Mencirim found farmers growing morning, maize, cassava, yams and other young plants. At the present time when the farming community Sei Mencirim enter the harvest, the problems encountered are agricultural waste. Agricultural waste, before entering the new planting season usually left alone to get in on the next planting season. Besides that also the farmers set fires to agricultural wastes. Though this agricultural waste is a very valuable item when processed with the technology used as feed material for fermentation.

Creating a prosperous society through socioeconomic empowerment which should be encouraged oriented resource utilization around. By utilizing social resources and the natural resources that exist will result in a strong community socially and economically. So the social problems facing the economy will be easily solved, which is based on the implementation of the people's economy through socio-economic 
empowerment group graziersersip through variation technology feed (feed fermentation).Fermented feed more digestible so that optimal nutrient absorption. With this pattern, the nutrients in the feed needs are met so that livestock growth will be faster when compared with normal feeding (grass), usually 2-4 times increased growth compared with regular feeding (grass). Poultry meat does not contain much fat as an ideal feed composition. Feed nutrients such as vitamins fulfilled with the content of SOC HCS in the feed. The waste manure does not smell like when eating regular feed or grass and eliminate the habit of looking for grass or ngarit and free-range. $\mathrm{Ngarit}$ or free-range finding sometimes very dangerous wild animals such caterpillars in place mengarit.

Improving the ability of reproduction of sheep feeding fermentate ersip result will eventually be able to increase the sheep population ersip more quickly because the sheep will ersip efficient in reproductive activity. Increasing the efficiency of reproduction is clearly going to increase livestock numbers quickly and more efficiently, as well as an increase in farmer income

\section{METHOD OF EXECUTION}

Stages of activities that have been carried out in the implementation of the devotion are as follows: Implementation of science and technology activities for the community Sei Mencirim, District of Deli Serdang Sunggal begins with data collection activities and the formulation of the problems faced by the partner. Based on the data obtained, variations in feed technology (fermented feed) ready to be done in groups of partners. Implementation of the service is done in several sessions, with the following stages:

1. The collection of data to identify potential local resources.

This activity is done at the beginning before the team carrying out the nomination of these activities in an attempt to identify the potential of local resources. At the time of data collection takes place, the ability of people to take advantage of agricultural waste for animal feed is still low. Agricultural waste is often an environmental problem, even some farmers postharvest burning of agricultural waste. Meanwhile, the existing sheep farmers still rely mengarit Mencirim Sei grass every day, mengarit Where the grass is very dependent on the weather, even if it rains pengarit not carry out the task to find grass. These are the things which be thinking of the team to propose devotion socio-economic empowerment group ersip sheep farmers through technology variation of feed (fermented feed).

2. Administrative management of the public service activities

Tim devotion realize that service activities can not be done without permission from the local government setempat, The administration has come out a letter of assignment No. 386 / UN5.2.3.2.1 / PPM / 2017 signed on August 16, 2017, which it commissioned a team to do the devotion with the title: Socio-Economic Empowerment Sheep Breeders Group Ersip Through Technology Variations Feed (Feed Fermentation). Before exiting mail this task, the team has visited Mr. Secretary Head of Village, just let you know that in the near future the team will perform in Sei Mencirim devotion. Mr. Head Village orally through Mr. village secretary does not mind about the service activities that will be conducted by a team. Service activities conducted by a team on the day/date of Saturday 26th and Sunday, August 27th, 2017.

3. Preparation of materials and technology initiation variation of feed (fermented feed), this activity was done on day/date of Saturday, August 26, 2017. This activity is carried out in phases:

- Extension, in the form of lectures and discussions on the individual level capacity building to build the group and build the capacity of the group at the level of structure and systems in the group of sheep farmers ersip.

- FGD, discussions were conducted to collect information on the opportunities that can be achieved with the implementation of the practice of making fermented feed sheep food for ersip. 
- Introducing the materials and tools that will be used for the practice of fermented feed.

4. On the day/date Sunday, August 27, 2017, carried out the fermentation feed manufacturing practices.

The training was conducted on a group of farmers domaersipdiSei village in interactive and participatory Mencirim associated with the implementation of an increase in sheep reproduction variations in feed fermentation technology,

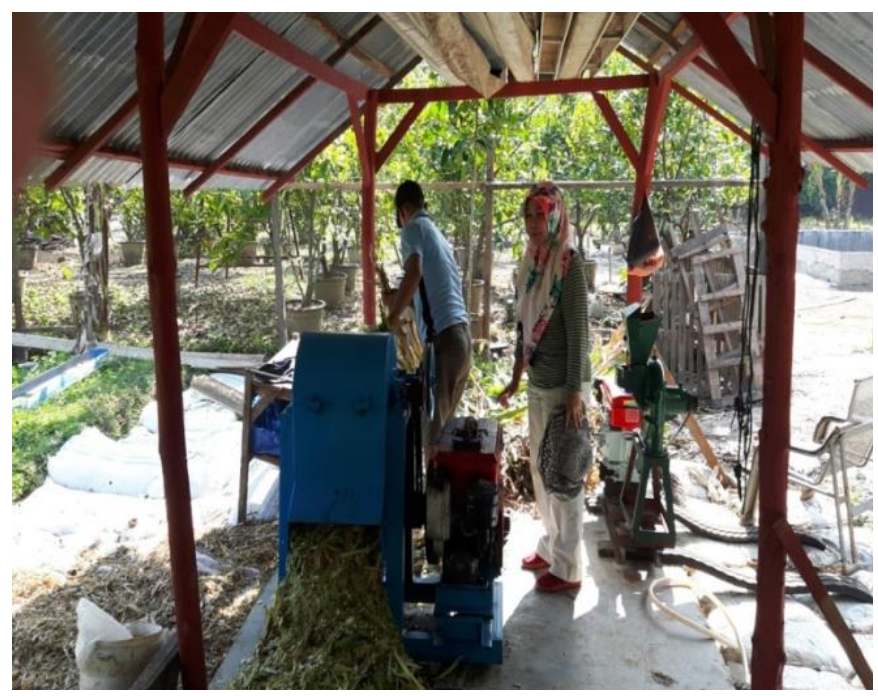

Figure 1: Mentoring Process Processed Feed

1. Ways of making Fermentation Feed

a. Spread a tarp in the shade, that is to say, let us not overheat during the work, or reduce the risk of damaged or dead inoculum.

b. On top of the tarp before, with paved with wood, agricultural waste already shredded to a size of $3 \times 4 \mathrm{~cm}$

c. Mixed with agricultural waste before the pulp and tofu, stirring until evenly, leave on for 15 minutes

d. After 15 minutes, a solution of fermented seeds was put into 10 liters of water 9pakai ember0 stir until dissolved

e. The solution is then put into a sprayer and sprayed with the ingredients that are mixed before, stirring until evenly distributed.

f. Then sprinkle 250 grams of salt into the material while stirring evenly. g. The final step, insert the material into the barrel plastic and sealed (airtight) for 1-3 hours

h. Once completed, the fermented feed is ready to be given to the sheep.

2. Another thing to note

a. Before the fermented feed was given to the sheep, it must first be cleaned or washed and also the cage must be clean. If necessary, the sheep were given vitamin B in advance in order to increase their appetite

b. Enter the sheep to the glittering cage and let the first to adapt and not be given directly eat.

c. For the adaptation process, first of all give fermented feed mixed with feed that have been sprayed with SOC HCS

d. During 1-7 days, every morning fed as usual that has been sprayed with SOC HCS. Afternoons fed fermentation.

\section{RESULTS AND DISCUSSION}

Ersip sheep farmers in the village of SeiMencirim before doing the old method that displeases them in terms of providing food for their animals. Food that is obtained by mengarit results is also not able to give a significant influence on the growth and reproduction of farm animals. Besides, it is also ignorance of the public using agricultural waste which is commonly found in Sei Mencirim in order to solve the economic trouble in the community.

Another major obstacle that is found is the inability of villagers to identifiying a potential source of social and natural resources owned. It takes the intervention of outsiders to encourage people to identify potential sources of social and natural resources available so that communities can make a map of a potential source of social and natural resources potential. Through this community service activities in SeiMencirim, particularly sheep farmers ersip able to explore their potential, both potential and the potential to maximize the existing resources in SeiMencirim.

Through this service activity for animal breeders to create a new product for animal feed that can enhance nutrient absorption livestock. With this 
pattern, the nutrients in the feed needs are met so that livestock growth will be faster when compared with normal feeding (grass), usually, 2-4 times increased growth compared with regular feeding (grass). Poultry meat does not contain much fat as an ideal feed composition. Feed nutrients such as vitamins fulfilled with the content of SOC HCS in feed. The waste manure does not smell like when eating regular feed or grass and eliminates the habit of looking for grass or ngarit and free-range. Ngarit or free-range sometimes very dangerous discovery of wild animals such as snakes in place mengarit.

With the existence of this public service activities Sei Mencirim able to build a group that can raise the level of their productivity. Through the processed fodder they create can increase the amount of income of the farmers. The increase in revenue is obtained from increasing the quality of their animals, on the other hand, the processed feed is abundant enough to be sold to farmers who came from another village.

\section{CONCLUSION}

The team has successfully established a team dedicated animal feed production fermentation in cooperation with ersip Sheep Breeders Group as partners in service. Service activities performed community service team Institute for Research and Community Service (LPPM) Field Service received a very good response from the target program. It can be seen from the enthusiasm of the participant's dedication in following each stage of devotion. Service activities have made it step production, use, and sale of animal feed fermentation.

\section{REFERENCE}

Budiman, Arif. 1995. Teori Pembangunan Dunia Ketiga, Jakarta: Gramedia Pustaka Utama, 12-16.

Cathart, R.S., and Larry A. Samovar, 1974. Small Group Communication : A Reader. New York : Holt, Rinehart and Winston, Inc.

Chamala, R.S., 1995. Overview of Participative Action Approaches in Australian Land and Water Management. Dalam Chamala, S. and Keith, K. (eds), 1995.Participative
Approaches for Landcare: Perspective, Policies, Program. Brisbane : Australian Academic Press.

Chambers, R. (1985). Rural development : putting the last first. London ; New York: Longman.

Hikmat, H., 2004. Strategi Pemberdayaan Masyarakat. Penerbit Humoniora, Bandung.

Kartasasmita, Ginandjar, 1996. Pembangunan Untuk Rakyat-Memadukan Pertumbuhan dan Pemerataan. Penerbit PT. Pustaka CIDESINDO, Jakarta.

Khairuddin, 2000. Pembangunan Masyarakat., Tinjauan Aspek: Sosiologi, Ekonomi dan Perencanaan. Liberty, Yogyakarta.

Hasbullah, Jousari. 2006. Social Capital, Menuju Keunggulan Budaya Manusia Indonesia, Jakarta: MR-United Press, 5.

Moeljiarto. dkk. 1997. "Bidang Pendidikan dan Kesehatan dalam Pembangunan Sosial" Dalam Analisis CSIS Pemberdayaan Masyarakat Lapis Bawah", Jakarta: CSIS. Tahun XXVI, No. 1. Januari-Februari 1997, 23.

Mubyarto. 2002. Pemberdayaan Ekonomi Rakyat dan Peranan Ilmu-Ilmu Sosial, Yogyakarta: Aditya Media. 13.

Suparjan. dkk. 2003. Pengembangan Masyarakat Dari Pembangunan Sampai Pemberdayaan Yogyakarta: Aditya Media, 52-55. 